Jurnal As-Salam, 2(1) Januari - April 2018
(Print ISSN 2528-1402, Online ISSN 2549-5593)

\title{
HISTORISITAS PEMIKIRAN FUNDAMENTALIS-EKSTRIMIS DALAM AGAMA ISLAM
}

\author{
Ruri Amanda \\ STAIN Gajah Putih Takengon, Aceh Tengah, Aceh \\ Email: ruri_islamologi@yahoo.co.id
}

\begin{abstract}
Abstrak. Secara historisitas dapat dikatakan komunitas Islam Khawarij adalah gerakan umat Muslim pertama yang menerapkan nilai-nilai ekstrimis keagamaan dalam sejarah umat Muslim. Ketika lahir pada era Ali bin Abi Thalib gerakan Khawarij bertindak layaknya seperti sekelompok "teroris" yang selalu mengintimidasi kehidupan umat beragama ketika itu. Dalam perjalanannya gerakan ini memang dapat ditumpas oleh pihak pemerintah Islam ketika itu namun tidak dengan pemikirannya. Ide-ide ekstrimis yang diramu oleh Khawarij seperti terus bertahan sepanjang zaman. Pada masa terkini banyak gerakan ekstrimis Islam yang berkiblat terhadap doktrin pemikiran Khawarij walaupun secara identitas mereka tidak mengakui sebagai bagian dari gerakan Khawarij namun jika ditelisik maka akan ditemukan benang merah yang begitu jelas antara pola pemikiran mereka dengan pola pemikiran Khawarij pada masa klasik. Ada satu kesamaan antara gerakan ekstrimis Islam pada masa kini dengan pola pemikiran Khawarij pada masa lampau yaitu sama-sama bersikap kaku dan jumud dalam mendefinisikan tekstualitas dalil pada agama Islam. Dibutuhkan adanya sikap edukasi dari para ulama dan cendekiawan Muslim untuk mengarahkan pemahaman umat Muslim agar bersikap lebih dinamis dalam menghadapi perbedaan dalam beragama. Sikap dinamis ini bukanlah hal baru dalam sejarah umat Muslim karena Nabi Muhammad SAW pernah mempraktekkan sikap dinamis yang begitu elegan dalam menghadapi komunitas Nasrani dan Yahudi di Madinah.
\end{abstract}

Kata kunci: ekstrimis, fundamentalisme, khawarij.

\section{A. Fundamentalisme Islam Masa Lalu dan Masa Kini}

Tidak bisa dipungkiri pada era sekarang muncul stigma negatif yang selalu mengaitkan Islam dengan berbagai macam tindakan kekerasan. Hal ini bisa jadi merupakan propaganda keji dari pihak-pihak yang tidak menyukai akan keberadaan Islam namun stigma negatif ini bisa pula muncul karena diakibatkan oleh kejumudan umat Muslim itu sendiri dalam memahami agamanya yaitu Islam. Para cendekiawan Muslim moderat menganggap gerakan Fundamentalisme Islam telah "berhasil" mengubah wajah Islam yang semula merupakan agama damai menjadi agama yang penuh dengan sikapsikap ekstrimis dan kekerasan.

Menurut Fazlur Rahman yang dimaksud dengan gerakan Fundamentalis Islam pada zaman modern ini adalah kelompok umat Islam yang menolak perubahan yang dihasilkan oleh modernisasi budaya dan intelektual. ${ }^{1}$ Kelompok ini tetap melaksanakan segala aspek ajaran Islam sesuai dengan apa yang telah diwariskan oleh ulama generasi awal baik dalam aspek hablumminallah maupun dalam aspek hablumminannas. Akibat penolakan dari modernisasi budaya dan intelektual ini adalah terjadinya ketertinggalan umat Islam dibandingkan dengan masyarakat kontemporer lainnya dalam bidang ekonomi, politik, ilmu pengetahuan dan aspek lainnya. ${ }^{2}$

\footnotetext{
${ }^{1}$ Fazlur Rahman, Gelombang Perubahan Dalam Islam, (Rajawali Press, Jakarta, 2000) hal.9

${ }^{2}$ Fazlur Rahman, Gelombang Perubahan.. hal.10
} 
John L. Esposito mengatakan istilah fundamentalis adalah istilah baru pada zaman modern ini yang diberikan kepada kaum muslim tradisional-konservatif yang sedang mengalami pertentangan dengan kaum moderat. ${ }^{3}$ Menurut Esposito, kaum tradisionalkonservatif ini mengalami degradasi pemahaman tentang wawasan Islam terutama dalam hal aspek Islam yang transenden (aspek Islam yang tidak bisa diubah, seperti shalat, puasa, zakat, haji, akidah) dengan aspek Islam yang partikular (aspek Islam yang bisa mengalami Ijtihad dan Tajdid, seperti perkawinan, perceraian, warisan, kontrak, bunga bank, pidana dan lainnya). ${ }^{4}$ Kaum moderat hanya menginginkan dihidupkannya kembali Ijtihad,Tajdid dan Ishlah dalam aspek Islam yang partikular bukan pada aspek yang Transenden. Padahal hakikatnya aspek Islam yang partikular ini adalah hasil ijtihad dan tajdid juga dari para ulama terdahulu.

Dari semua perbenturan ini, keberadaan kaum fundamentalis semakin dipertanyakan dan disangsikan oleh kaum moderat sebagai salah satu sandungan kemajuan umat Islam. Pada masa awal Islam telah muncul Mu'tazilah sebagai kelompok Islam yang rasional tetapi walaupun kelompok ini sangat mengagungkan dinamisasi akal namun kelompok ini tetap tidak bisa dianggap sebagai kelompok moderat karena konsep pemikiran Mu'tazilah masih tetap lebih banyak terikat dengan nash-nash Al-Quran dan hadits secara kaku. ${ }^{5}$ Sesuatu yang disesalkan sejarah adalah dinamisasi akal Mu'tazilah lebih banyak berkutat pada hal-hal yang transenden bukan pada hal yang partikular. Berbeda dengan kaum Islam moderat pada saat ini yang menginginkan dinamisasi akal hanya pada yang partikular bukan pada yang transenden.

Selain keberadaan kelompok Mu'tazilah sebagai kelompok Tradisional-Rasional, terdapat pula kelompok sektarianisme Khawarij sebagai kelompok Tradisional-Ekstrem yang banyak melakukan tindakan kriminalitas dalam menyebarkan pahamnya kepada masyarakat. Kelompok Islam ekstrem pada masa modern ini banyak yang mengadopsi pemikiran takfir Khawarij dalam melegalisasi aksi terornya dalam masyarakat

Diantara semua kelompok yang ada, kaum Islam Tradisional-Konservatif adalah konsep pemikiran umat Islam yang paling tua dan eksistensinya terus bertahan sampai pada masa ini walaupun pada saat ini kelompok ini mulai dipertanyakan eksistensinya dan terus didesak oleh kaum Islam-Moderat. Kaum Islam Tradisional-Konservatif ini pada masa awal Islam adalah kelompok yang masih mempertahankan semangat sami'na wa atha'na (kami dengar dan kami patuhi). Kelompok ini menolak rasionalisasi dalam memahami aspek akidah Islam seperti yang digencarkan oleh kelompok Mu'tazilah dan tidak menerima sikap radikalisasi dalam melaksanakan ajaran Islam seperti yang dilakukan oleh kelompok Khawarij. Kelompok Tradisional-Konservatif cenderung memilih sikap menghindar jika menemui persoalan yang tidak bisa dicerna oleh akal, seperti persoalan sifat takdir, keberadaan Allah dan persoalan lainnya yang tidak bisa dicapai oleh akal. Di masa selanjutnya kelompok ini akan mentransformasikan dirinya menjadi aliran Asy'ariyah dan Maturudiyah sebagai reaksi atas hegemoni pengaruh Mu'tazilah yang mencapai masa keemasannnya pada zaman khalifah Al-Ma'mun. ${ }^{6}$

Pada pembahasan selanjutnya akan dibahas perkembangan sejarah lahirnya kelompok-kelompok fundamentalis Islam pada masa awal perkembangan ilmu kalam.

\footnotetext{
${ }^{3}$ John L.Esposito, Masa Depan Islam, (Mizan, Jakarta,2010) hal. 149

${ }^{4}$ John L.Esposito, Masa Depan.. Hal.149

${ }^{5}$ Toshihiko Izutsu, Konsep Kepercayaan dalam Teologi Islam, (Tiara Wacana Yogya, Yogyakarta, 1994)

${ }^{6}$ Imam As-Suyuthi, Tarikh Khulafa', (Alkautsar, Jakarta, 2010) hal.120
} 


\section{B. Awal Mula Munculnya Gejolak Kekerasan Dalam Internal Islam}

Pada tanggal 8 Juni $632 \mathrm{M}$ wafatlah Rasulullah SAW. yang mengakibatkan kebingungan luar biasa pada masyarakat Muslim ketika itu. Tidak ada satu sosok manusia pun yang bisa menggantikan Muhammad sebagai Rasul dan juga tidak ada satu orang pun yang berani mengajukan diri untuk menggantikan Rasul. Untuk menghilangkan kebingungan ini maka dicarilah seseorang untuk menggantikan Rasul hanya dari segi fungsi kepemimpinan negara saja. Maka terpilihlah Abu Bakar untuk menggantikan fungsi Rasul sebagai seorang pemimpin negara. Karena terpilihnya Abu Bakar hanya untuk mengisi kekosongan kepemimpinan negara yang ditinggalkan Muhammad maka Abu Bakar memakai gelar khalifah, dalam arti lafzinya adalah pengganti ${ }^{7}$. Kemudian dalam kurun waktu berikutnya Umar bin Khattab pun diangkat sebagai khalifah selanjutnya untuk menggantikan Abu Bakar yang telah wafat.

Setelah Umar bin Khattab mangkat, maka umat Muslim sepakat untuk membai'at Utsman bin Affan sebagai khalifah selanjutnya. Khalifah Utsman memiliki prestasi emas yag sangat terkenal yaitu berhasil mengkompilasikan tulisan-tulisan Al-Quran menjadi sebuah buku yang kemudian menjadi kopian resmi dalam mencetak Al-Quran di seluruh penjuru benua. Namun, pada masa khalifah Utsman lah benih-benih konflik mulai bermunculan menggerogoti suasana perpolitikan pemerintahan ketika itu. Ahli sejarah melaporkan bahwa Utsman adalah seorang pemimpin yang lemah pendirian karena tidak mampu melawan ambisi keluarga besarnya yang kaya raya dan berpengaruh di tanah Arab ketika itu. Salah satu isu yang sangat menyudutkan Utsman adalah isu nepotisme yang dilakukannya. Isu ini sangat beralasan karena Utsman secara terang-terangan mencopot sejumlah Gubernur yang pernah diangkat oleh Khalifah Umar dulu dengan orang-orang yang memiliki kedekatan secara pribadi dan kekeluargaan dengan Utsman. Misalnya, Amr ibn al-Ash seorang Gubernur Mesir yang diangkat oleh Khalifah Umar pada waktu sebelumnya langsung dicopot dari jabatannya dan digantikan dengan Ibn Abi Sarh yang merupakan salah satu anggota keluarga Utsman. Tindakan Utsman ini menuai kecaman dari para Sahabat lainnya karena bertolak belakang dengan karakter Umar yang tidak pernah mementingkan kepentingan pribadi dan keluarganya. Reaksi keras bermunculan dimana-mana, salah satu yang paling kritis adalah bergeraknya 500-an pemberontak dari Mesir menuju Madinah untuk menggulingkan Utsman. Suasana panas di Madinah mengakibatkan terbunuhnya Utsman di tangan salah seorang pemberontak dari Mesir yaitu, Wardan bin Samurah. ${ }^{8}$

Utsman wafat pada tanggal 17 Juni 656 M. Roda kepemimpinan kekhilafahan bergulir pada Ali bin Abi Thalib yang di bai'at di Mesjid Nabawi Madinah pada tanggal 24 Juni 656 M. Tetapi Ali pun tidak bisa menjalankan tugasnya sebagai khalifah dengan tenang, karena di masa kepemimpinannya Ali mendapat intervensi politik yang luar biasa dari rival-rival politiknya yang juga menginginkan posisi khalifah. Thalhah dan Zubair, mereka adalah salah satu rival politik Ali yang tidak senang dengan kepemimpinan Ali sebagai Khalifah. Pertikaian politik ini berujung pada sebuah peperangan yang bernama Perang Jamal. Perang Jamal ini selain membawa dampak negatif bagi pemerintahan Ali juga memberikan beban moral yang sangat luar biasa bagi Ali karena salah satu pemuka yang menunggangi perang ini adalah 'Aisyah, janda Rasul yang sangat dihormati kaum Muslim. Dinamakan perang Jamal karena dalam peperangan ini 'Aisyah menunggangi seekor unta. Karena Ali memiliki kekuatan militer yang lebih unggul sebagai seorang

\footnotetext{
${ }^{7}$ Prof.Dr Katimin, Mozaik Pemikiran Islam, (Cita Pustaka, Medan, 2010)hal.6

${ }^{8}$ Prof.Dr Katimin, Mozaik.. hal.7
} 
khalifah, perang Jamal yang dimotori 'Aisyah ini dapat diredam dengan ditandai tewasnya Thalhah serta Zubair dan 'Aisyah sebagai pihak yang kalah mendapatkan pengampunan dengan dikirimkannya beliau kembali ke Madinah. Sejarah mencatat peperangan yang penuh dengan beban moral ini terjadi pada tanggal 9 Desember $656 \mathrm{M}^{9}$

28 Juli $657 \mathrm{M}$ adalah tanggal yang memiliki catatan kelam bagi karir perpolitikan Ali sebagai Khalifah. Karena pada tanggal ini Mu'awiyah bin Abi Sufyan seorang Gubernur Damaskus yang masih memiliki hubungan kerabat dengan Utsman secara terang-terangan menyatakan konfrontasinya kepada khalifah Ali bin Abi Thalib. Mu'awiyah menuntut kepada Ali agar menghukum para pemberontak yang melakukan pembunuhan terhadap Utsman. Bahkan Mu'awiyah menuduh Ali memiliki andil dalam tewasnya Utsman, hal ini diyakini Mu'awiyah karena terlibatnya anak angkat Ali dalam pemberontakan Mesir yang mengakibatkan tewasnya Utsman, yaitu Muhammad ibn Abi Bakr. Dan yang lebih disesali Mua'wiyah adalah diangkatnya pula Muhammad ibn Abi Bakr sebagai Gubernur Mesir. Krisis politik ini akhirnya mengakibatkan terjadinya konfrontasi Militer antara Ali dan Mu'awiyah dalam sebuah peperangan yang bernama Perang Siffin, yang terjadi pada 1 Shafar $37 \mathrm{H}^{10}$

Pada saat terjadi perang Siffin antara kubu Ali dan kubu Mu'awiyah, keadaan sudah sangat menguntungkan bagi Ali sehingga sebenarnya Ali sudah bisa mengalahkan kubu Mu'wiyah pada saat itu juga. Di tengah keterdesakan Mu'awiyah muncullah salah seorang pendukung Mu'awiyah di tengah peperangan seorang diplomat yang sangat ulung yaitu Amru bin 'Ash. Amru mengangkat Al-Quran di ujung tombak sebagai tanda isyarat untuk melakukan perdamaian dengan pihak 'Ali.

Sebenarnya dari awal Ali sangat menolak tawaran untuk melakukan perundingan perdamaian dengan pihak Mu'awiyah, tetapi karena desakan yang sangat kuat dari para ahli qurra (Ahli Al-Quran) untuk melakukan perdamaian seperti Asy'atsbin Qais, Mas'ud bin Fudaki al-Tamimi dan Zaid bin Husein al-Tha'i, maka 'Ali pun menerima tawaran perundingan perdamaian dengan pihak Mu'awiyah. Maka perdamaian pun dilakukan dengan cara rapat umum/hakam (arbitrase). Arbitrase ini dilakukan pada bulan Januari $659 \mathrm{M}$ di Adhruh.

Dalam pelaksanaan perdamaian itu, kubu Ali menunjuk Abu Musa al-Asy'ari sedangkan dari pihak Mu'awiyah dipilih Amr bin al-Ash sebagai juru rundingnya. Dalam perundingan tersebut, Abu Musa al-Asy'ari dan Amr bin al-Ash sepakat melakukan perdamaian dengan cara menurunkan Ali dari jabatan sebagai Khalifah dan juga menurunkan Mu'awiyah dari jabatan sebagai Gubernur. Hal ini dilakukan untuk memperoleh rasa keadilan diantara kedua belah pihak.

Ketika tiba masa pengumuman hasil perundingan, Abu Musa al-Asy'ari sebagai wakil dari pihak Ali dipersilahkan terlebih dahulu untuk mengumumkan hasil perundingan yaitu diturunkannya Ali dari posisi Khalifah. Kemudian ketika giliran Amr bin al-Ash untuk mengumumkan hasil perundingan terjadilah kecurangan yang dilakukan oleh pihak Mu'awiyah dimana Amr bin al-Ash menolak untuk menyatakan bahwa Mu'awiyah telah diturunkan sebagai Gubernur. Amr bin al-Ash malah berkata:

"Sekarang sudah kita dengar pengumuman bahwa Ali telah dijatuhkan sebagai khalifah, maka dengan sudah jatuhnya Ali, satu-satunya pemimpin kita yang akan menjalankan rodapememerintahan adalah Mu'awiyah bin Abi Sofyan"

\footnotetext{
${ }^{9}$ Prof.Dr.Katimin, Mozaik.. hal.7

${ }^{10}$ Prof.Dr.Katimin, Mozaik.. hal.8
} 
Kondisi ini sangat menguntungkan bagi Mu'awiyah dan merugikan Ali. Tetapi walau begitu Ali tetap tidak mau melepaskan jabatannya sebagai Khalifah karena Ali tetap menganggap dirinya adalah sebagai khalifah yang sah (legal) dan Mu'awiyah sebagai khalifah yang tidak sah (ilegal). Walaupun Mu'awiyah dianggap sebagai khalifah yang tidak sah tetapi secara massa dan politik terjadi dualisme kepemimpinan, keadaan yang kacau ini akhirnya menghantarkan Ali kepada kematiannya pada tanggal 24 Januari 661 M yang terbunuh di tangan salah seorang pengikut Khawarij Abdul Rahman Ibn Muljam. Ali terbunuh ketika sedang melakukan perjalanan ke Mesjid Kuffah.

Sesuatu yang menarik adalah gejolak politik yang terjadi semenjak masa khalifah Umar bin Khattab dan mencapai puncaknya pada masa khalifah Ali bin Abi Thalib inilah yang menjadi penyebab utama lahirnya aliran-aliran teologi untuk pertama kalinya dimasa awal Islam. Dimulai sejak tahun $657 \mathrm{M}$ yang ditandai dengan lahirnya aliran teologi Khawarij lalu diikuti Syi'ah, Mu'tazilah, Murji'ah hingga mencapai puncaknya pada sekitar tahun $930 \mathrm{M}$ hingga $945 \mathrm{M}$ yang ditandai dengan lahirnya aliran Asy'ariyah dan Maturudiyah yang merupakan perwujudan reaksi dari gerakan Mu'tazilah yang sangat mengagungkan dominasi akal dalam memahami agama.

\section{Sejarah Lahirnya Aliran Khawarij Sebagai Pencetus Gerakan Ekstrem}

\section{Faktor politik}

Khawarij secara historis lahir pada tahun $657 \mathrm{M}$ tepat sesaat setelah terjadinya perang Siffin. Khawarij dapat dikatakan sebagai aliran teologi tertua dalam dunia Islam sekaligus pelopor lahirnya berbagai aliran teologi lainnya dalam dunia Islam. Pada awalnya aliran khawarij lahir bukan karena persoalan teologis dalam Islam melainkan karena persoalan politik yang sengit.

Salah satu peristiwa kelam yang menggegerkan penduduk Madinah adalah peristiwa terbunuhnya khalifah Utsman bin Affan. Terbunuhnya Utsman bin Affan akibat adanya fitnah yang menimpa Utsman bin Affan. Salah satu penyebab yang semakin membuat fitnah ini tersulut adalah isu nepotisme yang membayangi pemerintahan Utsman bin Affan. Seperti yang diketahui bahwa semasa pemerintahannya, Utsman bin Affan banyak mengangkat para kerabatnya dalam posisi-posisi penting di tubuh pemerintahan, misalnya Mu'awiyah bin Abu Sofyan yang menduduki posisi Gubernur Syam, Abdullah bin Sa'ad bin Abu Sarh menduduki jabatan Gubernur Mesir, Abdullah bin Amir menduduki jabatan gubernur Bashrah sehingga Utsman bin Affan dituduh lebih mengutamakan kesejahteraan para kerabatnya dalam mengelola pemerintahan. Akibat dari fitnah ini adalah munculnya gerakan-gerakan pemberontakan yang ingin menggulingkan pemerintahan Utsman bin Affan. Klimaks dari pemberontakan ini adalah tewasnya Utsman bin Affan di tangan salah seorang pemberontak dari Mesir yaitu Wardan bin Samurah. ${ }^{11}$

Di tengah situasi yang genting ini maka Ali lah satu-satunya tokoh umat Islam kala itu yang mampu menggantikan Utsman sebagai khalifah dan dipercaya mampu meredam pemberontakan-pemberontakan yang muncul. Akhirnya Ali dibaiat sebagai khalifah pada tanggal 25 dzulhijah atau 24 Juni $656 \mathrm{M}$.

Tuntutan pertama yang dihadapi Ali ketika pertama memangku jabatan khalifah adalah menjatuhkan hukuman bagi para pembunuh Utsman bin Affan. Hal ini ditujukan agar kestabilan sistem kekhilafahan Islam dapat normal kembali. Langkah pertama Ali

\footnotetext{
${ }^{11}$ Prof.Dr.Katimin, Mozaik.. hal. 7
} 
sebagai khalifah untuk meredam fitnah yang masih berkobar adalah dengan memecat semua pejabat tinggi yang dulu pernah diangkat oleh Utsman bin Affan karena pangkal utama dari kenapa timbulnya pemberontakan ini adalah ketidaksukaan para pemberontak terhadap pejabat-pejabat yang masih memiliki kolega dengan Utsman bin Affan. Fitnah yang muncul adalah Utsman hanya mementingkan pejabat yang berasal dari kerabatnya saja. ${ }^{12}$

Maka pada masa awal pemerntahaannya Ali lagsung memecat Mu'awiyah bin Abu Sofyan dari posisi Gubernur Syam. Abdullah bin Sa'ad bin Abu Sarh dari jabatan Gubernur Mesir, Abdullah bi Amir dari jabatan gubrnur Bashrah dan Abu Musa Al Asy'ari dari Gubernur Kufah. Akibat dari pemecatan-pemecatan ini muncul banyak reaksi keras salah satunya berasal dari Mu'awiyah bin Abi Sufyan yang sangat menolak pemecatan yang dlakukan oleh Ali. Bahkan Mu'awiyah berani menolak kedatangan Sahl bin Hanif yang ditunjuk oleh Ali sebagai Gubernur baru Syam untuk menggantikan Mu'awiyah.

Ali terus menuntut Mu'awiyah agar mau mengakui dan membai'at Ali sebagai khalifah yang sah tetapi Mu'awiyah baru mau mengakui Ali sebagai Khalifah apabila Ali telah berhasil menangkap dan menghukum para pembunuh Ali, terlebih lagi antara Muawiyah dan Utsman masih terdapat hubungan kekerabatan yang masih sangat dekat. Selain itu Mu'awiyah menganggap Ali terlibat dalam rencana pembunuhan Utsman bin Affan. Hal ini beralasan karena anak angkat Ali yaitu Muhammad ibn Abi Bakr terlibat dalam pemberontakan Mesir yang menyebabkan tewasnya Utsman bin Affan. ${ }^{13}$

Di tengah perseteruan antara Ali dan Muawiyah ini tiba-tiba pasukan kaum Muslimin yang dipimpin oleh Aisyah bersama Thalhah dan Zubair melakukan penyerangan kepada Ali. Alasan penyerangan ini hampir serupa dengan motif Muawiyah yaitu sama-sama berkaitan dengan kematian Utsman yang harus dipertanggungjawabkan oleh Ali. Akhirnya meletuslah perang Jamal antara kubu Aisyah yang didukung oleh Thalhah dan Zubair dengan kubu pemerintahan Khalifah Ali. Perang ini terjadai paada tahun $36 \mathrm{H}$. Perang ini pun dimenangkan oleh Ali yang ditandai dengan tewasnya Thalhah dan Zubair serta Aisyah yang mendapat pengampunan dan dikirim pulang kembali ke Medinah.

Tepat setahun kemudian yaitu pada tahun $37 \mathrm{H}$ meletuslah perang Shiffin yang terjadi akibat semakin sengitnya perseteruan antara Muawiyah dengan Ali. Perang ini berlangsung selama 10 hari dan telah memakan banyak korban. Peperangan ini baru berhenti setelah dilakukan tahkim (arbitrase)oleh Abu Musa al-Asy'ari dan Amr bin Ash. Sebelum keputusan diambil, kedua belah pihak menyetujui untuk menurunkan Ali dan Muawiyah dari jabatannya masing-masing. Abu Musa mendapat giliran pertama untuk mengumumkan pemunduran Ali tetapi Amr bin Ash malah melakukan kecurangan ketika mendapat giliran untuk mengumumkan keputusannya. Amr bukan mengumumkan keputusan pemunduran Muawiyah melainkan pengukuhan Muawiyah sebagai khalifah.

Pada awal mulanya Khawarij adalah pendukung setia Khalifah 'Ali bin Abi Thalib yang mendukung Ali dalam melawan konfrontasi pasukan Mu'awiiyah dalam perang Siffin. Namun, pada akhirnya kaum khawarij merasa kecewa dan menuai kebencian kepada khalifah Ali bin Abi Thalib. Penyebabnya adalah keputusan 'Ali yang menerima perundingan perdamaian/Arbitrase dengan pihak Mu'awiyah. Kaum Khawarij

\footnotetext{
${ }^{12}$ Sami Abdullah al-Maghluts, Atlas Agama Islam, (Al-Mahira, Jakarta, 2009) hal.112

${ }^{13}$ Prof.Dr.Katimin, Mozaik..hal.7
} 
menilai Ali tidak pantas melakukan perundingan perdamaian dengan pihak yang melakukan bughat/makar. Perbuatan Mu'awiyah yang melakukan pemberontakan harus ditumpas dan diatasi dengan cara menggunakan hukum yang tertulis dalam Al-Quran. Kaum Khawarij menarik dukungannya kepada Ali dengan mengatakan "Mengapa kalian berhukum kepada manusia. Tidak ada hukum selain hukum yang ada di sisi Allah." Ali pun balas menjawab "Itu adalah ungkapan yang benar, tetapi mereka artikan dengan keliru". ${ }^{14}$ Adapun landasan dalil yang digunakan kaum khawarij adalah:

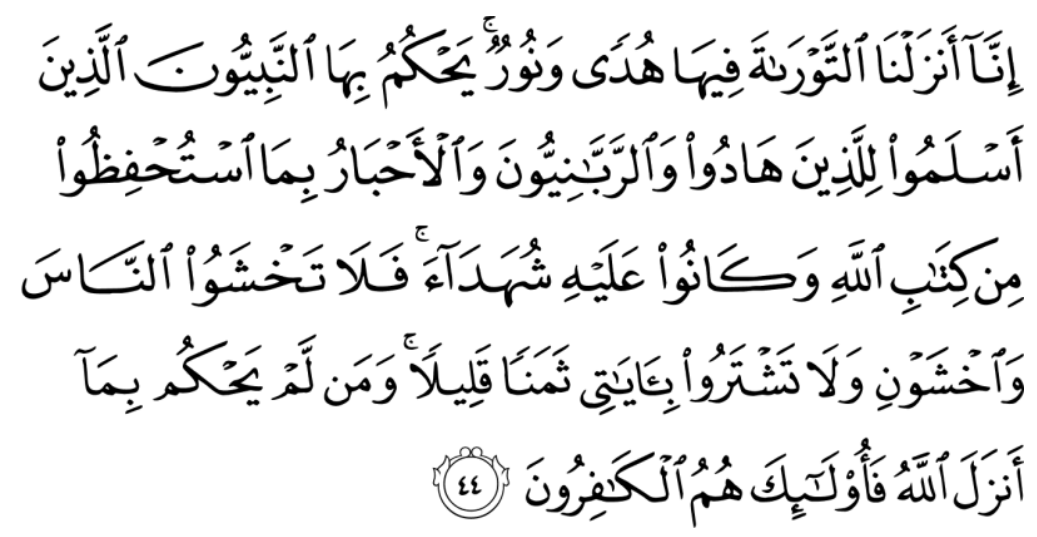

Sesungguhnya Kami telah menurunkan kitab Taurat di dalamnya (ada) petunjuk dan cahaya (yang menerangi), yang dengan kitab itu diputuskan perkara orangorang Yahudi oleh nabi-nabi yang menyerah diri kepada Allah, oleh orang-orang alim mereka dan pendeta-pendeta mereka, disebabkan mereka diperintahkan memelihara Kitab-Kitab Allah dan mereka menjadi saksi terhadapnya. karena itu janganlah kamu takut kepada manusia, (tetapi) takutlah kepada-Ku. dan janganlah kamu menukar ayat-ayat-Ku dengan harga yang sedikit. Barangsiapa yang tidak memutuskan menurut apa yang diturunkan Allah, Maka mereka itu adalah orang-orang yang kafir.

Setelah mereka mengkafirkan Ali dan pihak lainnya yang ikut terlibat dalam Arbitrase ini, kaum khawarij melepaskan dukungannya kepada Ali dan keluar dari barisan kelompok Ali. Karena keputusan mereka untuk keluar (khawarij) dari barisan Ali inilah yang menyebabkan mereka dinamakan dengan kaum Khawarij yaitu orang yang keluar dan memisahkan diri.

\section{Faktor Sosial}

Selain karena faktor politik yang menyebabkan lahirnya kelompok Khawarij ternyata kondisi sosial juga turut mempengaruhi lahirnya kelompok ini. Sebagian besar orang-oraang Khawarij berasal dari kalangan Arab Badui yang memiliki kedangkalan intelektual jika dibandingkan dengan kaum Muslim yang bertempat tinggal di pusat kota Medinah maupun Mekkah.Selain itu letak geografis tempat tinggal mereka yang sangat berjauhan dengan domisili Rasul di pusat kota Medinah maupun Mekkah sehingga mereka tidak bisa setiap saat menjumpai Rasul dalam melakukan sharing mengenai masalah agama Islam. Akibatnya banyak aspek ajaran Islam yang mereka pahami berdasarkan nalar dan intelektual mereka yang dangkal. ${ }^{15}$ Namun, waalaupun begitu mereka memiliki semangat yang tinggi dalam melaksanakan secara aplikatif ajaran-ajaran

\footnotetext{
${ }^{14}$ Prof.Dr.Katimin, Mozaik...hal.18

${ }^{15}$ Abu Mujahid, Teror NII, (Toobagus, Bandung, 2011) hal.57
} 
Islam sehingga di kemudian hari kaum khawarij ini memiliki semangat fundamentalis membabi buta yang tidak didukung oleh pemahaman Islam secara komprehensif. Banyak ayat-ayat Alquran yang masih bersifat mutasyabihat yang mereka tafsirkan menurut logika mereka saja dengan tujuan untuk mendukung doktrin ajaran mereka.

\section{Pokok Ajaran Khawarij}

Pokok ajaran dasar kaum Khawarij adalah bahwa pelaku dosa besar adalah kafir. Pada awal mulanya pandangan mereka tentang konsep takfir ini adalah sebagai reaksi keras kaum khawarij dalam menanggapi suasana politik yang terjadi sejak perang Jamal hingga Perang Siffin. Menurut mereka segala pihak yang terlibat dalam perang Jamal (Perang antara 'Aisyah, Thalhah, Zubair dengan Ali) dan segala pihak yang terlibat dalam Arbitrase perang Siffin dihukumi sebagai kafir mutlak. Karena semua pihak yang terlibat dalam dua perang tersebut telah menggunakan hukum manusia dalam menyelesaikan konflik dan bukan hukum Allah seperti yang tercantum dalam dalam AlQuran. Dalil utama mereka adalah Surat Al-Maidah ayat 44. Kemudian pada waktu selanjutnya pandangan takfir menjadi persoalan teologis yang selalu diperdebatkan hingga melahirkan aliran-aliran teologis lainnya untuk menaggapi permasalahan ini seperti Mu'tazilah dan Murji'ah

Kebanyakan pengikut aliran Khawarij ini adalah orang Arab Badui. Cara pola pikir mereka masih sangat sederhana dan kaku tetapi mereka memiliki komitmen iman serta ibadah yang kuat. Akibatnya mereka menjadi sangat picik dan fanatisme, sehingga mereka tidak memahami bagaimana mentolerir perbedaan dalam bidang pemahaman agama. Setelah mereka mendeklarasikan diri sebagai bagian dari Khawarij mereka semakin berani mengkafirkan bahkan tidak segan untuk melakukan pembunuhan jika ada yang berani menentang pemahaman mereka.

Berikut adalah pokok ajaran Khawarij lainnya dan beberapa diantaranya tergolong sangat ekstrem;

- Khalifah atau Imam harus dipilih secara bebas oleh umat Islam

- Khalifah tidak harus berasal dari kalangan Arab, setiap Muslim berhak menjadi khalifah asalkan memenuhi syarat

- Seseorang harus menghindar pimpinan yang menyeleweng

- Seseorang yang berdosa besar tidak lagi disebut Muslim sehingga halal darahnya untuk dibunuh

- Setiap Muslim harus bergabung dengan kelompok Khawarij jika tidak maka wajib dibunuh

- Adanya wa'ad dan wa'id (Janji dan Ancaman). Yaitu Allah berjanji akan memberikan pahala bagi setiap Muslim yang berbuat baik dan begitu pula sebaliknya Allah akan memberikan balasan Azab bagi setiap orang yang melakukan kejahatan. Termasuk bagi setiap Muslim yang melakukan dosa besar maka akan dihukumi dan diberikan azab sebagai orang kafir. Jadi dalam pandangan kaum khawarij, tidak ada harapan bagi setiap Muslim yang melakukan dosa besar untuk mendapat pengampunan dari Allah. Setiap Muslim yang melakukan dosa besar akan dihukumi sebagai kafir.

- Amar ma'ruf nahi munkar. Konsep ini disalah pahami oleh kaum khawarij sebagai dalil untuk melakukan tindakan kekerasan bagi setiap Muslim yang bertentangan atau menolak bergabung dengan kelompok Khawarij.

- Meghindarkan diri dari ayat-ayat Al-Quran yang bersifat Mutasyabihat. 
- Manusia bebas menentukan perbuatannya dan tidak ada campur tangan dari Tuhan.

Khawarij yang terkenal dengan konsep takfirnya ini dalam perkembangannya terpecah menjadi 6 sekte. Diantara 6 sekte yang ada terdapat beberapa perbedaan dalam pemahamannya. Ada yang berpahaman sangat ekstrem dan ada pula yang berpahaman lebih toleran. Ke enam sekte itu adalah:

a) Al-Muhakkimah

Al-Muhakkimah adalah gelar bagi pengikut Khawarij pada generasi awal. Merekalah yang pertama kali mencetuskan bahwa Ali dan Muawiyah serta pihak lainnya yang terlibat dalam arbitrase perang Siffin adalah pelaku dosa besar dan mereka semuanya harus dihukumi sebagai orang kafir. Dalam perkembangan selanjutnya pemikiran mereka mengalami perkembangan lebih jauh lagi, dimana mereka menegaskan perbuatan dosa lainnya seperti berzina, membunuh, meminum khamr dan perbuatan dosa besar lainnya dapat menyebabkan pelakunya menjadi kafir. Adapun tokoh-tokoh yang menjadi pemuka dalam generasi awal Khawarij ini adalah Abdullah bin alKiwa', Atab bin A'war dan Abdullah bin Wahb al-Rasibi.

b) Al-Azariqah

Inilah sekte Khawarij yang terkenal karena konsep pemikirannya yang ekstrem dan radikal. Nama sekte dinisbatkan kepada tokoh sentralnya yaitu Nafi bin al-Azraq. Nafi bin al-Azraq melalui pemikiran kakunya telah menjadikan sekte ini menjadi sekte yang radikal dan ekstrem. Menurut Toshihiko Izutsu dalam bukunya "Konsep Kepercayaan Dalam Teologi Islam" sekte Azariqah ini adalah terorismenya Khawarij. Mereka beranggapan semua Muslim yang berseberangan pandangan dengan Khawarij dianggap Kafir dan Musyrik sehingga boleh dibunuh. Bahkan secara ekstrem dibebankan kewajiban bagi setiap pengikut Khawarij Al-Azariqah untuk menumpas setiap Muslim yang tidak mau mengikuti pandangan mereka. Pada tingkatan yang lebih ekstrem lagi, walau seorang Muslim tersebut sepaham dengan pemahaman Khawarij tetapi jika tidak mau bertempat tinggal di daerah kekuasaan Khawarij maka tetap dianggap kafir serta musyrik dan juga boleh dibunuh. Sekte ini menamakan tempat tinggal mereka dengan nama Darul Hijra sedangkan tempat tinggal kaum Muslim yang berseberangan paham dengan mereka dinamakan Darul Kufur. ${ }^{16}$ Berikut adalah pandangan Ibnu Hazm yang dikutip secara langsung oleh Toshihiko Izutsu $^{17}$;

"Azariqah berpendapat bahwa, apabila mereka menjumpai seorang Muslim yang tidak menjadi anggota perkemahan mereka, maka mereka harus ditanyai (sambil mengacungkan pedang) mengenai keyakinan agamanya. Apabila ia mengatakan 'Saya Seorang Muslim' maka mereka membunuh orang tersebut di tempat itu juga. Tetapi mereka melarang membunuh siapapun yang menyatakan ia adalah seorang Yahudi, atau seorang Kristen atau seorag Majusi"

Adalah sesuatu yang sangat ironi ketika mereka membunuh setiap Muslim yang tidak tinggal di kawasan perkemahan mereka. Tetapi apabila mereka menjumpai seorang

\footnotetext{
${ }^{16}$ Fazlur Rahman, Gelombang Perubahan Dalam Islam, (Rajawali Press, Jakarta 2000)

${ }^{17}$ Toshihiko Izutsu, Konsep Kepercayaan Dalam Islam, (Tiara Wacana Yogya, Yogyakarta,1994)hal.15
} 
Kristen atau Yahudi ataupun Majusi maka mereka langsung memberikan perlindungan. Sebuah logika yang kacau.

Toshihiko Izutsu menyimpulkan ada tiga macam pemikiran Khawarij Azariqah yang tidak boleh dicontoh oleh kebudayaan manapun, yaitu: pertama, Semua orang Muslim yang tidak mengikut pendapat mereka sampai pada hal yang sekecil-kecilnya adalah musyrik. Kedua, Semua Muslim walaupun sepakat dengan Khawarij Azariqah secara teoritik tetapi tidak mau melakukan "migrasi suci" ke wilayah perkemahan mereka maka tetap dianggap musyrik dan kafir Ketiga, Semua istri dan anak-anak dari para Muslim yang telah dianggap musyrik itu dianggap juga sama musyriknya seperti suami atau ayah mereka. Sehingga mereka dapat ditumpas dan dibunuh tanpa batas serta hartanya dirampas sebagai harta ghanimah.

Keekstreman pemikiran sekte Al-Azariqah ini banyak dipengaruhi oleh pemikiran kaku pemimpinnya Nafi bin Al-Azraq dalam memahami Al-Quran. Banyak ayat AlQuran yang dipahami Nafi dengan picik dan kaku. Diantaranya Hukuman cambuk 80 kali bagi yang menuduh wanita baik-baik berzina seperti yang tercantum dalam surat An-Nuur ayat 4-5 hanya dipakai jika yang menuduh itu adalah wanita. ${ }^{18}$ Sedangkan jika yang menuduh adalah pria maka hukuman cambuk ini tidak berlaku.

Selain itu hukuman mati untuk perzinahan itu tidak sah karena menurut Nafi hal tersebut tidak tercantum dalam Al-Quran. Hukum Rajam pun tidak diakui mereka karena Al-Quran dianggapnya tidak pernah menyebutkan tentang hal ini. ${ }^{19}$

Di kalangan sekte ini Nafi bin Al-Azraq dianggap sebagai seorang faqih yang mampu memberikan otoritas fatwa. Pemikiran kritisnya yang teologis ini diperoleh dari seorang gurunya yang merupakan salah satu Sahabat Rasulullah yaitu Abdullah bin Abbas.

Karena keekstreman mereka hampir tidak bisa dicerna logika lagi maka tidak heran jika ada beberapa pengikut Khawarij yang memutuskan diri untuk keluar dari aliran Azariqah ini dan mendirikan sekte baru yang memiliki pemikiran lebih toleran dibandingkan dengan Azariqah, misalnya Al-Najdah dan Al-Suffriyah.

c) Al-Najdah

Abu Fudaik adalah salah satu pelopor lahirnya sekte ini. Pada awalnya Abu Fudaik adalah pendukung setia dari sekte Azraqiyah. Tapi ada beberapa pemahaman dari Azraqiyah yang kurang disenangi oleh Abu Fudaik yaitu pemaksaan harus tinggal di daerah kekuasaan Azraqiyah. Bersama beberapa orang pendukungnya Abu Fudaik pergi ke Yammah untuk melindungi diri dari kecaman sekte Azraqiyah. Di tengah perjalanannya Abu Fudaik bertemu dengan Najdah bin Amir al-Hanafi. Pada awalnya Najdah bermaksud ingin bergabung dengan sekte Azraqiyah tetapi Abu Fudaik mencegahnya dan mempengaruhi Najdah agar membentuk sekte Khawarij yang lebih toleran. Akhirnya mereka sepakat untuk membentuk sekte baru dengan Najdah sebagai pimpinannya. Sehingga sekte ini dinamakan dengan "Al-Najdah".

Sekte ini agak berbeda jika dibandingkan dengan sekte Al-Azariqah maupun Muhakkimah. Sekte ini berpendapat walaupun seorang Muslim berseberangan pendapat dengan Khawarij tetapi tidak akan kekal dalam neraka dan akan tetap masuk

\footnotetext{
${ }^{18}$ Fazlur Rahman, Gelombang Perubahan Dalam Islam, (Rajawali Press, Jakarta, 2000)

${ }^{19}$ Abu Mujahid, Teror..hal.98
} 
surga juga walau harus menerima siksaan dulu. Berbeda dengan Azariqah yang mengatakan seorang Muslim yang berseberangan pendapat dengan Khawarij adalah kafir dan akan kekal dalam neraka. Selain itu sekte An-Najdah juga menolak pemikiran tentang adanya Darul Hijrah dan Darul Kufur. ${ }^{20}$

d) Al-Suffriyah

Sekte ini dipimpin oleh Ziad bin Al-Safar. Menurut catatan sejarah sekte ini dianggap yang paling moderat jika dibandingkan dengan sekte lainnya. Paham-paham mereka yang lebih moderat adalah:

- Orang Suffriyah yang tidak mau berhijrah ke Darul Hijra tidak akan dianggap kafir

- Anak-anak dari kaum muslim yang dianggap musyrik dan kafir tidak boleh dibunuh

- Daerah tempat tinggal kaum Muslim yang tidak sepaham dengan mereka tidak boleh diserang tetapi yang boleh diserang adalah daerah pemerintahan

- Anak-anak serta perempuan tidak boleh dijadikan tawanan

- Kufur dibagi dua yaitu "kufr bi inkar al-nikmah" (mengingkari nikmat Tuhan) dan "kufr bi inkari al-Rububiyah" (mengingkari adanya Tuhan). Sehingga bagi Suffriyah term "kafir" tidak selamanya harus keluar dari agama Islam.

e) Al-Azaridah

Salah seorang pelopor berdirinya sekte ini adalah 'Athiyah al-Hanafi. Pada awal mulanya 'Athiyah adalah pendukung sekte Al-Najdah namun karena terjadi perselisihan akhirnya 'Athiyah melepaskan diri dari sekte tersebut. Dengan mengajak salah seorang temannya Abdul Karim bin Al-Azrad mereka berdua sepakat untuk membentuk sekte baru dengan Azrad sebagai pimpinannya. Itulah sebabnya kenapa sekte ini dinamakan dengan Al-Azaridah.

Selain memiliki perbedaan pemikiran dengan sekte-sekte lainnya tapi satu pemikirannya yang paling menonjol adalah anggapan Al-Azaridah yang tidak mengakui Surat Yusuf sebagai bagian dari Al-Quran. Mereka beranggapan surat Yusuf adalah surat yang berisi tentang cerita cinta sedangkan Al-Quran itu adalah Wahyu Allah sehingga tidak mungkin di dalamnya terdapat cerita cinta. Akibat pandangannya ini sekte Al-Azaridah ini dianggap sekte sesat dan kafir mutlak.

f) Al-Ibadiyah

Nama sekte ini diambil dari nama pemimpinnya yaitu Abdullah bin Ibad. Awalnya Abdullah bin Ibad adalah pengikut sekte Al-Azariqah tetapi karena mengalami perselisihan dalam hal pemahaman akhirnya Abdullah bin Ibad memisahkan diri dan membentuk sekte baru. Sekte yang didirikannya ini memiliki pemikiran yang juga moderat sama halnya dengan sekte Al-Suffriyah. Paham-paham yang dianut oleh AlIbadiyah adalah

- Orang Muslim yang tidak sepaham dengan Khawarij bukanlah golongan kafir dan bukan pula golongan musyrik, tetapi mereka adalah kafir nikmat.

${ }^{20}$ Yoshihiko Izutsu, Konsep Kepercayaan..hal.43 
- Boleh melakukan hubungan perkawinan dan hubungan warisan dengan orang Muslim yang tidak sepaham degan mereka. Membunuh orang Muslim yang tidak sepaham dengan mereka adalah haram.

- Yang boleh dirampas dari kaum Muslim yang tidak sepaham dengan mereka hanyalah kuda dan senjata. Sedangkan emas dan perak harus dikembalikan kepada pemiliknya.

\section{Kekerasan Atas Nama Agama Islam Pada Masa Kini}

Kekerasan dalam salah satu bentuknya seperti perang merupakan salah satu warisan peradaban dunia yang sering dijadikan sebagai media "efektif" dalam membangun suatu peradaban bangsa. Namun walaupun begitu tidak ada satu agama pun yang melegalisasi kekerasan dalam menyebarkan keyakinan dan akidahnya. Hakikatnya kekerasan dalam agama boleh digunakan hanya dalam rangka untuk "membela diri" dan bukan untuk tujuan "Ekspansionis". Baik agama Islam, Kristen maupun Yahudi memiliki akar pemahaman yang sama dalam hal ini.

Hanya saja para pemeluk dari suatu agama tertentu terkadang mengalami "Lost Control" sehingga agama sering dijadikan alasan untuk membenarkan suatu kekerasan. Constantine mengaku menerima bisikan Ilahi "Dengan Salib Engkau Akan Menang". Constantine menjadikan bisikan ini sebagai inspirasi untuk melakukan suatu peperangan. $^{21}$

Jika di era klasik terdapat kelompok khawarij yang melegalisasi kekerasan atas nama agama Islam maka di era modern pun terdapat kelompok-kelompok "Jihad" Islam yang melegalisasi kekerasan atas nama agama. Pemboman gedung World Trade Center di Amerika pada 11 September 2001, Kasus Bom Bali di Indonesia tahun 2002 dan kasus-kasus kekerasan ekstrimis lainnya dimana pihak Islam dituding sebagai pelakunya merupakan contoh dari perilaku umat Islam yang mengalami "Lost Control" dalam mengaplikasikan agamanya. Padahal sejarah membuktikan bahwa banyak tokoh-tokoh umat Islam yang sadar akan kemungkinan penyalahgunaan konsep jihad. Umar bin Khattab pernah melarang suatu ekspedisi militer karena tercium semangat materialisme dan penindasan yang tersembunyi di balik konsep jihad. Umar bin Abdul Aziz salah seorang khalifah yang terkenal bijaksana dalam dinasti Umayyah pernah memerintahkan para tentaranya yang telah mengepung Konstantinopel untuk kembali ke pangkalan. Umar bin Abdul Aziz mengucapkan kata-katanya yang terkenal; "Tuhan mengutus Muhammad untuk memberi petunjuk bukan untuk mencari Jizyah". ${ }^{22}$

Dalam sejarah Nabi Muhammad pun tercatat bahwa Allah sering menasehati Rasul agar bersabar menghadapi sikap bebal kaum musyrik Arab karena Muhammad diutus untuk membawa risalah perdamaian bukan risalah kekerasan. Perang-perang yang pernah dilancarkan Rasul semata-mata hanya untuk pembelaan diri bukan ekspansionis.

Dalam istilah Alquran terdaapat dua istilah tentang Jihad yaitu Jihad fi Sabilillah dan Jihad fillah. Jihad fi Sabilillah merupakan usaha sungguh-sungguh dari seorang Muslim dalam beragama di jalan Allah. Kesungguhan ini dibuktikan dengan pengorbanan harta dan nyawa. Hilangnya nyawa dalam suatu konfrontasi fisik merupakan bukti

\footnotetext{
${ }^{21}$ Alwi shihab, Islam Inklusif, (Mizan, Bandung, 1999) hal.289

${ }^{22}$ Alwi shihab, Islam.. hal. 283 
tertinggi dari Jihad fi Sabilillah. Salah satu contoh aplkasi yang paling tepat dalam Jihad fi Sabilillah adalah mengorbankan harta dan nyawa demi kemerdekaan suatu bangsa. ${ }^{23}$

Kategori jihad kedua adalah Jihad fillah yaitu usaha sungguh-sungguh untuk mendekatkan diri kepada Allah SWT melalui peningkatan aspek spritualisme dan penundukan aspek hawa nafsu melalui Tazkiyatun Nafs (penyucian jiwa). ${ }^{24}$ Dalam suatu hadis Nabi yang populer jihad yang seperti ini adalah jihad yang sesungguhnya dan lebih hakiki.

Untuk memperjelas substansi jihad agar tidak diidentikkan dengan angkatan bersenjata maka Alquran membedakan antara konsep Jihad dan konsep Qital (mengangkat senjata). Jihad merupakan pemahaman yang komprehensif dan luas tentang usaha sungguh-sungguh dalam memperjuangkan agama sedangkan Qital adalah salah satu aspek yang menjadi bagian kecil dari sisi-sisi yang dimiliki jihad. ${ }^{25}$

Aspek Qital dalam jihad dibatasi pada saat-saat tertentu saja terutama dalam rangka mempertahankan diri. Hal ini terungkap dalam Surah Al-Baqarah ayat 190-191

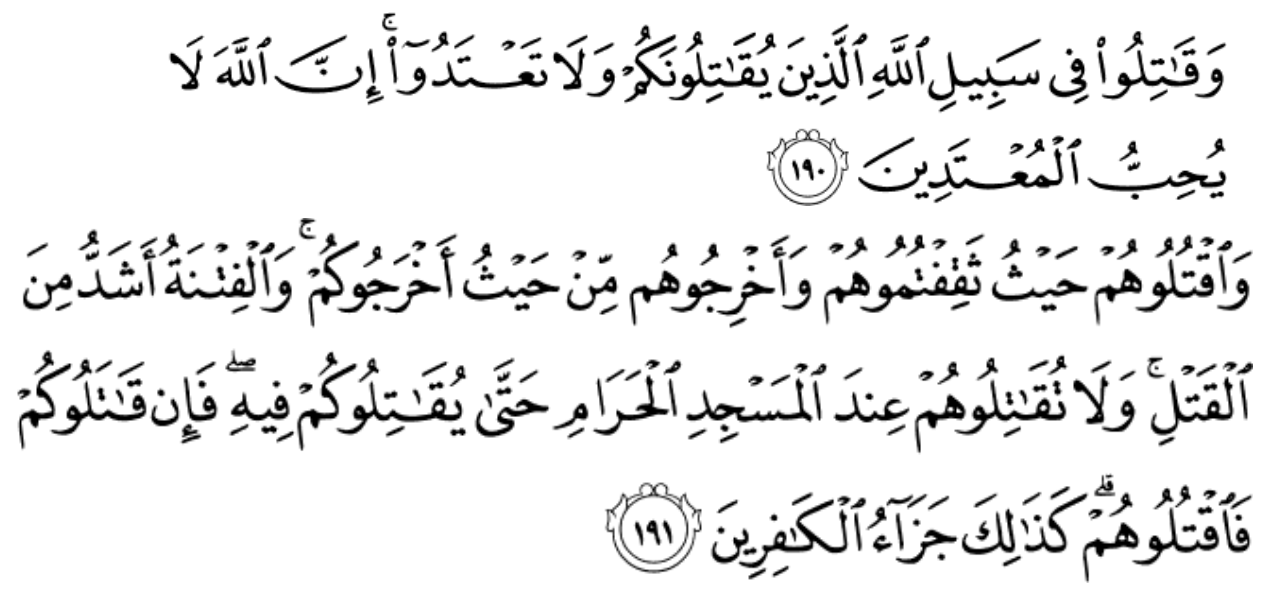

Artinya: 190. dan perangilah di jalan Allah orang-orang yang memerangi kamu, (tetapi) janganlah kamu melampaui batas, karena Sesungguhnya Allah tidak menyukai orang-orang yang melampaui batas. 191. dan bunuhlah mereka di mana saja kamu jumpai mereka, dan usirlah mereka dari tempat mereka telah mengusir kamu (Mekah); dan fitnahitu lebih besar bahayanya dari pembunuhan, dan janganlah kamu memerangi mereka di Masjidil haram, kecuali jika mereka memerangi kamu di tempat itu. jika mereka memerangi kamu (di tempat itu), Maka bunuhlah mereka. Demikanlah Balasan bagi orang-orang kafir.

Hanya saja aspek qital yang menjadi bagian kecil dari sisi-sisi jihad sering di general kan menjadi arti tunggal dari istilah jihad. Akibat dari pengertian sempit ini muncul perdebatan dan antagonisme baik antar sesama cendekiawan Muslim maupun dengan pihak orientalis. Perbedaan pendapat ini telah dimulai sejak zaman Islam klasik dahulu. Pada masa Utsman bin Affan terdapat tiga kelompok besar yang terlibat dalam perdebatan ini, yaitu;

\footnotetext{
${ }^{23}$ Ibnu Qayyim Al-Jauziyah, Zadul Ma'ad Jilid 3 (Alkautsar, Jakarta, 2008) hal. 4

${ }^{24}$ Syekh Muhammad al-Ghazali, Nahw tafsir Mawdhu'i Li Suwar al-Quran, (Serambi, Kairo, 2003) hal. 102

${ }^{25}$ Alwi shihab, Islam.. hal.285
} 
Pertama, Kelompok radikal Khawarij yang membenarkan penggunaan senjata dalam mengubah status quo. Kelompok ini berpendapat bahwa adalah kewajiban umat Islam bahkan setiap individu untuk berjihad mengangkat senjata guna menegakkan keadilan sesuai dengan perintah Tuhan. Kelompok ini secara kurang bijaksana memberi tekanan kuat kepada aspek tertentu dari ajaran Islam tanpa mengindahkan akibat samping dari penekanan tersebut. Ketidakadilan bagi mereka adalah sama dengan kezaliman dan kezaliman tidak ubahnya dengan kekufuran, sehingga pada gilirannya mereka yang berlaku tidak adil harus diperlakukan sama dengan orang-orang kafir harbi.

Kedua, Kelompok Syiah menjadikan Jihad sebagai salah satu pilar ajaran mereka. Berbeda dengan khawarij, mereka beranggapan bahwa jihad itu wajib dilakukan jika menghadapi pemerintahan kotor, zalim dan korup. Dalam hal ini Dinasti Umayyah merupakan contoh nyata dari sebuah pemerintahan yang dilawan dengan semangat jihad.

Ketiga, kelompok mayoritas umat Islam. Kelompok ini menahan diri dari keterlibatan dalam kemelut politik dan menganut sikap moderat. Mereka ini dipimpin oleh sahabat-sahabat Nabi yang terkemuka. Mereka menyatakan tidak berpihak dan membentuk kelompok non-blok demi menjaga persatuan dan kesatuan umat Islam. Mereka inilah yang merintis golongan Ahlussunnah wal Jamaah. Kelompok inilah yang berkembang pesat dan menjadi mayoritas umat Muslim hingga saat ini.

Seperti yang diungkapkan pada halaman sebelumnya salah satu faktor yang menyebabkan lahirnya sikap fundamentalis terutama dikalangan Khawarij adalah latarbelakang sosial mereka yang lahir sebagai kaum Badui. Mereka mengalami ketertinggalan intelektual jika dibandingkan dengan orang Arab lainnya yang tinggal di Mekkah dan Medinah. Selain itu karena faktor geografis jugalah mereka mengalami hambatan komunikasi dengan Rasulullah sehingga mereka tidak pernah mendengar ajaran Islam langsung dari Rasulullah secara maksimal dan komprehensif. Akibatnya di kemudian hari mereka memahami ajaran Islam dengan pandangan yang sempit dan kaku. Banyak ayat-ayat yang mereka pahami secara "tekstual kaku" tanpa memahami penjelasan lebih lanjut tentang sebuah ayat. ${ }^{26}$ Salah satu ayat yang sangat mereka pahami secara keliru adalah surah Al-Maidah ayat 44 yang artinya:

Sesungguhnya Kami telah menurunkan kitab Taurat di dalamnya (ada) petunjuk dan cahaya (yang menerangi), yang dengan kitab itu diputuskan perkara orangorang Yahudi oleh nabi-nabi yang menyerah diri kepada Allah, oleh orang-orang alim mereka dan pendeta-pendeta mereka, disebabkan mereka diperintahkan memelihara Kitab-Kitab Allah dan mereka menjadi saksi terhadapnya. karena itu janganlah kamu takut kepada manusia, (tetapi) takutlah kepada-Ku. dan janganlah kamu menukar ayat-ayat-Ku dengan harga yang sedikit. Barangsiapa yang tidak memutuskan menurut apa yang diturunkan Allah, Maka mereka itu adalah orang-orang yang kafir.

Berdasarkan ayat inilah mereka secara membabi buta mengkafirkan kelompok Ali, Kelompok Muawiyah serta semua pihak yang telah terlibat dalam peristiwa Tahkim perang Siffin. Berbeda dengan kaum khawarij di masa lalu; kaum fundamentalis pada zaman modern ini melancarkan serangkaian aksi kekerasannya karena lebih dipengaruhi oleh faktor eksternal. Di antara sebab yang dapat digolongkan sebagai sebab-sebab

\footnotetext{
${ }^{26}$ Luqman bin Muhammad Ba'abduh, Teroris Dalam Tinjauan Syariat (Pustaka Qaulan Sadida, Jakarta, 2005) hal. 73
} 
eksternal itu adalah tindakan-tndakan yang dilakukan negara-negara atau orang-orang Barat terhadap negara atau komunitas Muslim. Dalam prakteknya, tindakan-tindakan itu dapat berupa penyerangan, penindasan atau bahkan pembantaian umat Muslim.

Sebagai misal adalah penyerangan, pendudukan, dan juga pendirian negara Yahudi/Israel di Palestina pada 14 Mei 1948. Tindakan yang dilakukan Israel yang juga disokong oleh negara-negara Barat merupakan salah satu contoh tepat dalam hal ini. Tindakan Israel itu jelas memancing kemarahan massal dan sikap militan dari kaum muslimin yang ada di dunia ini. Sampai hari ini, masalah palestina-Israel menjadi topik pembicaraan kaum muslimin. Banyak dai kaum muslimin yang berusaha mengobarkan semangat keislaman pada diri mereka jika menyinggung masalah Palestina-Israel.

Dalam keadaan tertekan akibat masalah Palestina yang belum selesai, sejumlah masalah terkait nasib kaum muslimin lainnya menyusul. Sengketa Rohingya, misalnya cukup menyulut rasa sakit kaum muslimin. Demikian pula nasib kaum Muslim di belahan bumi lainnya yang tertindas karena sikap represif umat non-Muslim. Keadaan mereka yang mengenaskan dan sikap masa bodoh dunia internasional terhadap penyelesaian masalah mereka menjadi faktor pendorong kebencian kaumMuslim di seluruh penjuru dunia. $^{27}$

Demikian pula, upaya politik Amerika Serikat yang menunjukkan sikap tidak simpatiknya terhadap dunia Islam turut bmengundang reaksi keras dari berbagai kelompok-kelompok umat Islam yang ada. Walaupun kelompok-kelompok tersebut memiliki perbedaan prinsip dalam beberapa hal tetapi mereka memiliki satu kesamaan yaitu kebencian kepada penjajah "Barat".

Terkait dengan perang Afghanistan yang pernah terekam dalam sejarah yang silam, terjadi semacam perangsang bagi kelompok yang bersemangatkan Neo-Khawarij. Sebagaimana yang telah umum diketahui, kamp-kamp di Afghanistan ketika itu berfungsi sebagai pusat pendidikan dan pelatihan. Para relawan Afghanistan mendapatkan latihan mengoperasikan berbagai jenis senjata api, meracik bom-bom buatan, mempelajari taktik perang gerilya, mengenal peralatan-peralatan yang di pakai oleh militer negara-negara Barat, membunuh dan meneror siapa saja yang dianggap musuh.

Penyerangan Amerika Serikat ke Afghanistan karena dianggap dalang pemboman gedung World Trade Center pada 11Septemer 2001 juga semakin menyulut kebencian umat Muslim kepada negara-negara dari belahan benua Barat sehingga muncul stereotipe umum bahwa negara Barat adalah musuh Islam.

Selain itu yang juga termasuk ke dalam faktor-faktor eksternal adalah usaha sejumlah negara Eropa dan Amerika yang ingin mengkampanyekan nilai-nilai yang bertentangan ajaran Islam ke dalam lingkungan masyarakat Muslim. Walau pada nyatanya kampanye tersebut berhasil diterima oleh mayoritas masyarakat Muslim, namun muncul pula reaksi keras dari kalangan minoritas muslim yang menentangnya. Untuk menampilkan persepsi bahwa kekuatan minoritas adalah kekuatan yang patut disegani maka kekerasan yang bersemangatkan fundamentalis agama dimunculkan.

Akibat dari hal-hal yang seperti ini maka muncul anggapan umum bahwa semua negara dari benua Barat adalah "orang jahat" yang ingin merongrong umat Muslim di dunia. Oleh karena itu mereka semua dianggap Kafir harbi yang wajib diperangi. Banyak kelompok umat Islam yang tidak bisa membedakan lagi mana pihak Barat yang anti

\footnotetext{
${ }^{27}$ John L.Esposito, Masa Depan ..hal.82
} 
Islam, netral atau bahkan pro-Islam sehingga muncullah kelompok fundamentalis Islam di era modern yang menjadikan Barat secara umum sebagai musuh absolut umat Islam di seluruh dunia. Dalam situasi yang paling terkini kemunculan ISIS (Islamic State of Irak Suriah) pada tanggal 9 April 2013 juga turut makin "memperburuk" stigma negatif yang melekat pada umat Muslim. Bahkan banyak pihak yang menganggap ISIS adalah "wajah asli" umat Muslim yang dianggap tidak mau berkompromi dengan ide-ide modernitas di luar pemikiran konservatifnya.

Secara historisitas aksi kekerasan yang muncul dan mengatasnamakan agama Islam banyak mengadopsi pemikiran Khawarij yang pernah lahir pada era klasik Islam. Pemikiran Khawarij dianggap sebagai solusi "instant" yang dapat melindungi umat Muslim dari rongrongan represif kaum non Muslim yang tidak bersimpati dengan Islam. Namun aktualisasi pemikiran Khawarij ini malah semakin berdampak buruk terhadap kaum Muslim sehingga dibutuhkan peran ulama/cendekiawan Muslim yang mampu berpikiran seimbang dan solutif. Diperlukan adanya tindakan edukatif yang masif untuk memahamkan umat Muslim bagaimana seharusnya agama Islam berposisi dalam kancah dunia Internasional dan bagaimana etika interaksi yang harus dibangun dihadapan umat manusia lainnya yang tidak memeluk agama Islam. Sejatinya dalam sejarah keislaman, Nabi Muhammad SAW pernah mencontohkan etika yang begitu mulia dalam berkomunikasi dengan umat non Muslim yaitu ketika beliau menerapkan pondasi komunitas masyarakat madani di Madinah.

\section{Daftar Pustaka}

Abu Mujahid, Teror NII, Toobagus, Jakarta, 2011.

Alwi Shihab, Islam Inklusif, Mizan, Bandung, 1999.

Fazlur Rahman, Gelombang Perubahan Dalam Islam (Edisi Terjemahan), Rajawali Press, Jakarta, 2000.

Ibnu Qayyim Al Jauziyah, Zadul Ma'ad, Alkautsar, Jakarta, 2008.

Imam As-Suyuthi, Tarikh Khulafa, Alkautsar, Jakarta, 2010.

John L. Esposito, Masa Depan Islam (Edisi Terjemahan), Mizan, Bandung, 2011

Katimin, Mozaik Pemikiran Islam, Cita Pustaka, Bandung, 2010.

Luqman bib Muhammad Ba'abduh, Teroris Dalam Tinjauan Syariat, Pustaka Qaulan Sadida, Malang, 2005.

Syekh Muhammad al-Ghazali, Nahw Tafsir Mawdhu' Li Suwar al-Quran, Serambi, Kairo, 2003.

Toshihiko Izutsu, Konsep Kepercayaan Dalam Islam (Edisi Terjemahan), Tiara Wacana Yogya, Yogyakarta, 1994. 